\title{
Psychological Factors Predicting Risk-Taking Propensity of Poultry Farmers
}

\author{
${ }^{1}$ Balogun, S. K, ${ }^{2}$ Ojedokun O. and Macaulay, O. I. \\ ${ }^{1}$ Department of Psychology, University of Ibadan, Ibadan, Nigeria, \\ e-mail: shyngle61@yahoo.com \\ ${ }^{2}$ Department of Pure and Applied Psychology, Adekunle Ajasin University, \\ Akungba-Akoko, Ondo State,Nigeria.
}

\begin{abstract}
The importance of perceived fear of failure, achievement motivation, and locus of control in explaining risk-taking propensity was tested among poultry farmers. A sample of 238 poultry farmers (133(55.9\%) males 105 (44.1\%) females), with ages ranged between 19 years and 70 years with a mean of 39 years $(S d=10.70)$ were randomly selected among members of Poultry Farmers Association of Nigeria (POFAN), Ibadan Branch. Using a correlational design, the following measures were used: Performance Failure Appraisal Inventory (PFAI), Need for achievement scale, Locus of Control Behaviour and Risk-taking propensity. Results indicate a significant joint influence of perceived of fear of failure, achievement motivation, locus of control, age and years of experience on risk-taking propensity of poultry farmers $\left(R^{2}=.58 ; F(5,232)=63.51\right.$; $p<.001)$. The independent predictions show significant independent influence of fear of failure on risk-taking propensity $(\beta=-.49 ; t=4.74 ; p=n . s)$. Also, need for achievement $(\beta$ $=.20 ; t=2.98 ; p<.01)$ and locus of control $(\beta=.34 ; t=3.36 ; p<.001)$ contribute significantly to variants in risk-taking propensity. The result also shows a significant effect of educational levels on risk-taking propensity of poultry farmers $(F(3,234)$ $=3.38 ; p<.01)$. Overall, the findings of this study hold perceived fear of failure, achievement motivation and locus of control are important in understanding risktasking propensity. Therefore, it is possible to achieve improvement in risk-tasking propensity among poultry farmers with psychological intervention. Training sessions, seminars and conferences organized for poultry farmers are important arenas for reducing fear of failure, improving need for achievement, locus of control, and healthy perception of risk-taking propensity, which could be important for individual, group and societal economyand well-being.
\end{abstract}

Key words: Risk taking propensity, locus of control, need for achievement, perceived fear of failure, poultry farming 


\section{INTRODUCTION}

In life many important decisions often require making choices among alternatives that vary in their level of risk. This may lead to either positive or negative consequences for the group or an individual once an option is chosen. For examples, the decisions to invest in a business venture, stock market, undergo a medical operation, or go to court are generally made without knowing in advance whether the venture would be successful, whether the market will go up, the operation will be successful, or the court will decide in one's favor. In other words, most people often make decisions under conditions of risk. According to cognitive psychologists and decision making theorists, risk refers to the perceived chance of loss (Furby and Beyth-Marom, 1992; Von Winterfeldt and Edwards, 1986; Yates and Stone, 1992). Rohrmann (2004) defines risk as the possibility of physical or social or financial harm/detriment/loss due to a hazard. This is the (dominating) 'negative' perspective; however, there is also a neutral perspective, i.e., risk as uncertainty about the outcomes (good and/or bad ones) of a decision; and a positive perspective, i.e., risk can be a 'thrill' (danger-induced feelings of excitement). In general, risk can be described as uncertainty of loss (Denenberg, 1964), uncertainty about loss (Mehr \& Cammack, 1961), or uncertainty concerning loss (Rabel, 1968).

In agriculture, risk taking propensity of farmers varies across individuals. For an example, Johnson, et.al.(1961) studied over 1,000 Midwestern farmers and found a relationship between willingness to accept risk and the types of farm crops grown. High risk takers were more likely to be in cash crops and stock feeding. Those intermediate in accepting risk were involved in dairy and tobacco farming; the least risk takers were in general farming. This kind of behavior can be self-limiting, in that unwillingness to accept risks can keep farmers from engaging in more profitable efforts. As noted by Kunreuther and Wright (1979), those who practice "safety-first farming" may be trapped by their own risk aversion. These findings suggest that in developed economy, risk taking propensity and its antecedents are incubators of entrepreneurial endeavor for the purposes of creating wealth for the individual, increasing the national GDP, providing more employment opportunities, and adding value to the society. However, little is known about the specific psychological predictors of individual variation in risk taking propensity among Nigerian, and specifically among poultry farmers. This is surprising because there are undoubtedly success stories in the livestock farming, and poultry farming is specifically gaining increasing attention from individuals and government worldwide as a means to achieve wealth creation and personal fulfillment (Shane and Venkataraman, 2000). The importance of poultry farming is also self-evident for the well being of economies as well as societies.

In addition, interaction with some executive officers and members of Poultry Farmers Association of Nigeria (POFAN) revealed that some poultry farm projects end in failure despite the fact that government has created institutional, legal, financial, and enabling business environment for poultry farmers to operate and increase their productivity. This suggests that some poultry farmers may not accurately perceive risks, 
causing them to invest in poultry projects that ultimately result in failure. If poultry farmers have faulty perceptions of their risk taking propensity, then their investment efforts are likely to be misdirected. Also failure to have accurate perception of risks involve in poultry farming may make poultry farmers to underestimate them and unknowingly make risky decisions. This kind of faulty perception of risk taking propensity has been found to be associated with little success in livestock farming (Elmore, \& Lewis, 1991; Woelke, 1991; Zeidner, 1991). Risk taking propensity is a cognitive phenomena and cognitive issues domicile in psychology; therefore a possible approach for avoiding failure in poultry farming projects lies in the concept of risk taking propensity and its psychological explanations in individual poultry farmer. By modeling predictors of risk taking propensity among poultry farmers, psychological intervention can be designed to reduce faulty perception of risk taking propensity with the hope that this intervention minimizes poultry farm project failure.

Decision making theory charts the course by which individuals determine whether or not to engage in a particular behavior. This theory assumes that individuals seek to satisfy their own needs and goals by making rational choices regarding which behaviors will minimize loss and maximize gains given environmental constraints (Gardner, 1993). While there are many different factors that may affect decision-making, two variables, risk perception and risk taking propensity appear to play a central role in decision-making involving risk (Keil, et.al. 2000). Risk perception has been defined as a decision maker's assessment of the risk inherent in a situation (Sitkin and Pablo, 1992). Risk taking propensity refers to the notion that many decision makers have consistent tendencies to either take or avoid actions that they feel are risky (Kogan \& Wallach, 1964; Harnett \& Cummings, 1980; Sitkin \& Pablo, 1992). Risk taking propensity also refers to business actions that can potentially lead to some form of loss, and the processes involved in making those behavioral choices (COMSIS Corporation \& Johns Hopkins University, 1995). Risk-taking propensity is exhibited if a prospect is preferred to a sure outcome with equal or greater expected value (Tversky and Fox, 1995). Risk taking may be defined in varied ways, and different disciplines hold different perspectives of risk taking. Risk taking attitude is a generic orientation (as a mind-set) towards taking or avoiding a risk when deciding how to proceed in situations with uncertain outcomes (Rohrmann, 2004). The focus of this study is on some psychological factors that may predict risk taking propensity among poultry farmers.

Some psychological factors related to risk taking propensity have been advanced in the literature. These factors include achievement motivation (Johnson, 1990), locus of control (Hendrickx et.al., 1992; Ward, 1993; Carland, et al. 1984; Stewart, Watson, et al, 1999), and fear of failure (Lopes, 1984, 1987). Shane (2003) also suggests that psychological factors influence the likelihood that people will exploit new venture opportunities. These factors are categorized into three general areas: motivational, core self-evaluation, and cognitions. Motivational factors include need for achievement, risk taking propensity, and desire for independence. Core self evaluation factors include 
locus of control and self-efficacy. Cognitions are beliefs and attitudes that influence how a person thinks and makes decisions. In this study, psychological factors (need for achievement and locus of control, and perceived fear of failure) are promising candidates for helping to explain economic behavior such as risk taking propensity among poultry farmers.

In psychological literature, need for achievement defined as an individual's expectation of doing something better or faster than others and better than the person's earlier accomplishments (McClelland, 1961) has received particular attention due to its relation with achievement-relevant outcomes (Elliot and McGregor, 1999) such as task performance and desire to show competence (Harackiewicz, et al., 1997). In a study, Ombok (1990, Cited in Mungai and Ogot, n.d.) reported that entrepreneurs who had high achievement motivation had a tendency towards risk taking. Johnson (1990) also found a relationship between achievement motivation and creation of new ventures. This makes need for achievement a possible predictor of risk taking propensity among poultry farmers.

Perception of where personal control (locus of control) lies may also be related to risk-taking propensity. Locus of control refers to the perceived control over the events in one's life (Rotter, 1966). People with internal locus of control believe that they are able to control what happens in their lives. On the other hand, people with external locus of control tend to believe that most of the events in their lives result from being lucky, being at the right place at the right time, and the behaviors of powerful individuals. People's beliefs in personal control over their lives influence their perception of important events, their attitude towards life, and their work behaviors. Research shows that internals tend to estimate probability of failure as lower and decide in favor of risky options (Hendrickx, et al, 1992). As an example of this tendency, internals are found to plan for expansion of their businesses even when unemployment rates are high (Ward, 1993). Internal locus of control also leads to greater risk-taking behavior (Carland, et al., 1984; Stewart, et al., 1999). These results suggest that poultry farmers with internal locus of control may have more tendencies to take risk compared to those with external locus of control.

An individual's perception of fear of failure defined by Atkinson (1957), McClelland, et al.(1953) as the motive to avoid failure in evaluative situations based on anticipatory shame upon failure may have influence on risk taking propensity. Horner (1968) conceptualized the motive to avoid failure as an expectancy value theory of motivation. In this theory approach, there are two factors which determine the motivation and direction of individual's behavior. The first factor is determined by the expectations or beliefs individual holds about the nature and likelihood of the consequences of actions. The second factor is the value of these consequences, considering the individual's particular motives (Horner, 1972). According to this theory, anxiety will be aroused if individual expects the consequences of an action to be negative, and this anxiety serves to inhibit that particular action. Thus, Horner proposed 
that, due to anticipated negative consequences of failure (such as social rejection), individual becomes anxious, and this anxiety inhibits performance. Because some individuals have a fear of failure than the others they will avoid activities that are expected to have negative consequences at all costs. Rather than face the humiliation of not being able to achieve success, thus failing the task, these individuals may choose not to engage in the activity at all. In this manner they save face with their peers. If the task is not attempted, it cannot be failed (Atkinson \& Feather, 1966; Atkinson, 1974). Therefore, perceived fear of failure may serve as an important construct of personality for investigations into risk taking propensity in ventures because feeling competent and confident may influence the choices people make and the courses of action they pursue. Conroy, et al. (2002), Sagar, et al. (2007) view fear of failure as the tendency to appraise threat to the achievement of personally meaningful goals when one fails in the performance. They suggest that failure is perceived as threatening, and feared, by individuals who associate it with aversive consequences. Lopez $(1984,1987)$ argued that an individual's risk propensity is significantly influenced by the degree to which he or she is motivated by hope or fear.

In addition, previous research has suggested that there were differences in risk perception between men and women, with women judging health, safety, and recreational risks (Slovic, 1997; Finucane et al., 2000; Flynn et al., 1994). However, Carland et al., (1995) indicated that females in their study displayed a lower level of risk taking propensity than did males. Carland et al., (1995) also affirmed that higher levels of education led to higher propensities for risk taking among the participants in their study. Research (e.g., Hisrich and Peters, 1998; Brush, 1992) also suggest that entrepreneurs are better educated that the general public. The education levels of entrepreneurs tend to be above average (Brockhaus, 1982).

The concept of risk propensity and its predictors have important implications for the theoretical modeling of risk-taking propensity and for practical insights into the psychological motives underlying individual's propensity to take risk. In terms of risk management, a better understanding of risk taking propensity and its predictors could contribute significantly to risk management for current and intending poultry farmers. Using psychological measures such as perceived fear of failure, achievement motivation, and locus of control, poultry farmers and intending poultry farmers with faulty perception of risk could be identified. Then those individuals could be worked with independently to enlighten them on how their personality factors contribute to their faulty perception of risk taking with the aim that this would help them in taking realistic risks in poultry farming and in other relevant areas. Findings from the study will also help researchers to realize the reason behind some choices made by individuals, especially in the area of risk taking propensity modification and psychological factors. 


\section{Hypotheses}

1. There will be significant independent and joint influence of perceived fear of success, achievement motivation, locus of control, age, and year of experience in poultry farming on risk-taking propensity.

2. Male poultry farmers will significantly report more risk-taking propensity than female poultry farmers.

3. There would be a significant influence of level of education on risk-taking propensity.

\section{METHODOLOGY}

Research Design: This study adopts a correlational research design to investigate the relationships among perceived fear of failure, achievement motivation, locus of control, and risk-taking propensity. This design allows measurement of several variables and their interrelationships simultaneously where the researchers did not actively manipulate any variable(s) of interest. This design also seems appropriate, given that this study sought to investigate whether perceived fear of failure, achievement motivation, and locus of control predict perceived risk-taking propensity. The independent variables are perceived fear of failure, locus of control, and need for achievement while the dependent variable is risk-taking propensity.

\section{Participants}

A total of two hundred and thirty eight $(n=238)$ poultry farmers randomly selected among members of Poultry Farmers Association of Nigeria (POFAN), Ibadan Branch participated in the study. Their ages ranged between 19 years and 70 years with a mean of 39 years $(\mathrm{sd}=10.70)$. One hundred and thirty three $(55.9 \%)$ of the participants are males while $105(44.1 \%)$ are females. In terms of marital status, $61(25.6 \%)$ of the participants were single, and $167(70.2 \%)$ were married while the remaining $10(4.2 \%)$ were in the other categories. Thirty-nine (16.4\%) of the participants have WASC/SCCE qualification, 69 (29\%) have OND/NCE certificates, 116 (48.7\%) have HND/B.Sc Degree while $14(5.9 \%)$ have postgraduate qualifications. Participants have been in poultry farming for 1 to 35 years. In other words, when asked to state the number of years they have been in poultry farming, responses ranged from 1 year to 35 years with a mean of 8.15 years $(\mathrm{SD}=7.17)$.

\section{Sampling Procedure}

Data for this study was obtained from 238 randomly selected members of Poultry Farmers Association of Nigeria (POFAN), Ibadan Branch who attended the association's monthly meeting at its secretariat situated within the Federal Ministry of Cooperative and Industry, Ikolaba, Ibadan, Oyo State. Using the simple random sampling method (odd-even technique), members whose names fall on even numbers on the attendance register were identified by the researcher through the help of the association's president and secretary. 


\section{Measurement of Variables}

In a bid to elicit information for this study, a structured questionnaire in English language that capture personal demographic data such as age, gender, marital status, years of poultry farming experience (Number of years), and level of education (whether primary secondary, diploma and/or Graduate/postgraduate; and other variables of interest (perceived fear of failure, achievement motivation, locus of control, and risktaking propensity) was administered.

Perceived fear of failure. This was assessed using the 25 items Performance Failure Appraisal Inventory (PFAI) developed by Conroy (2003). The scale measures the strength of individuals' beliefs in five aversive consequences of failing. Scores are provided for each of these five lower-order fears of failing: (a) fear of experiencing shame and embarrassment, (b) fear of devaluing one's self-estimate, (c) fear of having an uncertain future, (d) fear of important others losing interest, and (e) fear of upsetting important others. The response format ranged from "Strongly Agree =1" to "Strongly Disagree $=5$ ", so that low score means low perception of fear of failure and high score indicate high perception of fear of failure. In this study, the researcher obtained an alpha coefficient of 0.79 and split half reliability coefficient of 0.76 for the scale.

Need for achievement. The need for achievement was measured using the 11 item need for achievement scale developed by Edward (1954) with a forced choice response format. The scale was however revised and shortened to 9 items with response on a 5 points Likert format of "Strongly Agree = 5" to "Strongly Disagree =1" by Oyefeso (1988). Low score on the scale means low need for achievement and high score indicates high need for achievement. As reported by Oyefeso (1988), the scale has a convergence validity of $\mathrm{r}=0.27(\mathrm{P}<.001)$ with subjects actual self-rating on perceived need for achievement. He also obtained a coefficient alpha of 0.78 and a stability coefficient of .22 . Babalola (2000) also reported an r coefficient of .60 using Spearman Brown reliability coefficient. In this study, the researcher obtained an alpha coefficient of 0.69 and split half reliability coefficient of 0.74 .

Locus of control. Individual perception of where the control of events in their life lay was assessed using the 17 items locus of control behavior index by Craig, et al. (1984). The response format ranged from "Strongly Agree =5" to "Strongly Disagree =1", so that high score means internal locus of control and low score indicate external locus of control. The following item had reversed scores: $2,3,4,6,9,10,11,12,14$, and 17. Craig, et al (1984) reported an alpha coefficient of 0.79 for the scale. In this study an alpha co efficient of 0 . 56 with Spilt- half reliability coefficient of 0.60 were obtained.

Risk-taking propensity was tapped using risk-taking propensity scale developed by Farley (1986). It is a 19 item self reported questionnaire with respondent format on a 5 points Likert format of "Strongly Agree = 5" to "Strongly Disagree =1", so that high score means more propensity to engage in risky projects and low score indicates less propensity to engage in risky projects. The following items were reversely scored: $2,56,8,9,10,12$, 15,17 and 19. Farley (1986) reported an internal consistency of 0.89 for the scale. In this 
study, the researcher obtained an alpha coefficient of 0.81 and split half reliability coefficient of 0.76 .

\section{Procedure}

Data for this study was obtained from 238 members of Poultry Farmers Association of Nigeria (POFAN), Ibadan Branch. Permission was first obtained from the executive members of the association and they were briefed on the purpose of the study. The attendance register of the members of the association who attended the monthly meeting was used to select participants into the study. Using simple random sampling method (odd-even technique), members whose names fall on even numbers on the attendance register were identified by the researcher through the help of the association's president and secretary. After this, participants' informed consent was obtained. A total of three hundred $(n=300)$ copies of questionnaire were administered to members identified to tap the relevant information for this study. Some of them filled the questionnaire instantly while some asked that they be allowed to take their questionnaire home and returning them at the next meeting. The secretary of the association was assigned with the responsibility of collecting the completed questionnaires back from members from whom the researcher retrieved same. After collection of completed questionnaires, the researcher checked through and removed those ones that were not properly filled. After this exercise, a total of two hundred and thirty eight copies of questionnaire $(79.33 \%)$ were eventually used. The properly completed were coded and scored for data analysis using SPSS statistically package.

\section{Data Analysis}

Analyses included descriptive statistics, correlation to examine the relationship among variables of the study, and simple linear multiple regression to test for the independent and joint influence of a number of independent variables (perceived of fear of failure, need for achievement, locus of control, age, and year of poultry farming experience) on the dependent variable (risk-taking propensity). t-test for independent sample was used to test for the difference in risk-taking propensity between male and female poultry farmers. Lastly, One-Way Analysis of Variance was used to compare participants with different levels of education on risk-taking propensity.

\section{RESULTS}

The first analysis involved correlations between predictor variables and the dependent variable in order to meet the requirements of multiple regression statistical analysis. the result is presented in Table 1. 
Table 1: Correlation Showing the Relationships Among the Variables of Study ( $n=238)$

\begin{tabular}{|l|cccccc|c|c|}
\hline Variables & 1 & 2 & 3 & 4 & 5 & 6 & Mean & S.D \\
\hline 1.Risk-Taking Propensity & - & & & & & & 56.35 & 11.22 \\
2. Fear of Failure & $-.53^{* *}$ & - & & & & & 68.50 & 14.08 \\
3. Need for Achievement & $.26^{* *}$ & $.43^{* *}$ & - & & & & 43.35 & 7.69 \\
4. Locus of Control & $.37^{* *}$ & $.62^{* *}$ & $.52^{* *}$ & - & & & 59.43 & 11.53 \\
5. Age & -.06 & .02 & -.03 & .02 & - & & 39.00 & 10.70 \\
6. Experience & -.02 & .02 & -.01 & .04 & .74 & - & 08.15 & 7.17 \\
\hline
\end{tabular}

$* *$ Correlation significant at 0.01

The results showed a moderate and significant negative relationship between perceived fear of failure and risk-taking propensity $(r=-.53 ; \mathrm{p}<.01)$. This means that when perceived fear of failure is low participants in this study report more risk-taking propensity. There is a low but significant positive relationship between need for achievement and risk-taking propensity $(\mathrm{r}=.26 ; \mathrm{p}<.01)$, suggesting that as participants' scores on need for achievement increase, risk-taking propensity increases. There is also a low but significant positive relationship between locus of control and risk-taking propensity $(\mathrm{r}=.37 ; \mathrm{p}<.01)$, indicating that when perception of control tends towards internality participants report more risk-taking propensity. However, there is no significant relationship between age $(r=-.06 ; p>.05)$ and risk-taking propensity. Lastly, year of poultry farming experience $(r=-.02 ; p>.05)$ has no significant relationship with risk-taking propensity. These results suggest that risk-taking propensity do not increase or decrease with changes in age and year of poultry farming experience.

Hypothesis one which predicted that there will be a significant independent and joint influence of perceived fear of failure, achievement motivation, locus of control, age, and year of poultry farming experience was tested with simple linear multiple regression statistical analysis. The result is presented in Table 2.

Table 2: Multiple Regression Analysis Showing Perceived Fear of Failure, Need for Achievement, Locus of Control, Age, and Year of Poultry Farming Experience as Predictors of Risk-Taking Propensity

\begin{tabular}{|l|c|c|c|c|c|c|}
\hline Variables & $\mathrm{R}^{2}$ & $\mathrm{~F}$ & $\mathrm{P}$ & & $\mathrm{T}$ & $\mathrm{P}$ \\
\hline Fear of Failure & & & & -.49 & -4.74 & $<.001$ \\
Need for & \multirow{2}{*}{63.51} & $<.001$ & .20 & 2.98 & $<.01$ \\
Achievement & & & & .34 & 3.36 & $<.001$ \\
Locus of Control & & & & -.08 & -1.18 & $>.05$ \\
Age & & & .02 & .27 & $>.05$ \\
Year of Experience & & & & & & \\
\hline
\end{tabular}


The result showed a significant joint influence of perceived of fear of failure, achievement motivation, locus of control, age and year of poultry farming experience on risk-taking propensity $\left(\mathrm{R}^{2}=.58 ; \mathrm{F}(5,232)=63.51 ; \mathrm{p}<.001\right)$. This shows that the five predictor variables jointly account for $58 \%$ of variance in risk-taking propensity of poultry farmers. The independent predictions show significant independent influence of fear of failure on risk-taking propensity $(\beta=-.49 ; \mathrm{t}=4.74 ; \mathrm{p}<.001)$, meaning that low scorers on perceived fear of failure are likely to exhibit more risk-taking propensity. Need for achievement $(B=.20 ; t=2.98 ; \mathrm{p}<.01)$ contribute significantly to variance in risk-taking propensity, meaning that high scorers on the need for achievement are likely to report more risk-taking propensity. Also, locus of control $(B=.34 ; t=3.36 ; p<.001)$ contribute significantly to variance in risk-taking propensity, suggesting that internalizers are likely to report more risk-taking propensity. Other results show that age $(\beta=-.08 ; \mathrm{t}=-1.18 ;$ p.n.s $)$ and year of poultry farming experience $(\beta=.02 ; \mathrm{t}=.27 ; \mathrm{p} . \mathrm{n} . \mathrm{s})$ do not significantly predict risk-taking propensity. These findings reveal that fear of failure, need for achievement, and locus of control contributed to the overall model. However, perceived fear of failure contributed more to explain risk taking propensity. Thus, hypothesis one is partially supported.

Hypothesis two which stated that male poultry farmers will significantly report more risk-taking propensity than female poultry farmers was tested using t-test for independent sample. The result is presented in table 3.

Table 3: Summary of t-test Analysis Showing the Difference on Risk-Taking Propensity Between Male and Female Poultry Farmers

\begin{tabular}{|llccccc|}
\hline Sex & $\mathrm{N}$ & Mean & S.D & Df & t & P \\
\hline Male & 133 & 97.22 & 21.84 & 235 & .71 & $>.05$ \\
\hline Female & 105 & 95.24 & 20.55 & & & \\
\hline
\end{tabular}

The result showed no significant difference on risk-taking propensity between male and female poultry farmers $(\mathrm{t}=.71 ; \mathrm{df}=235 ; \mathrm{p}=\mathrm{n} . \mathrm{s})$. This means that both male $(\mathrm{M}=$ $97.22)$ and female $(M=95.24)$ poultry farmers are likely to exhibit the same levels of risktaking propensity. Therefore, hypothesis two is rejected.

Hypothesis three which stated that there would be a significant influence of educational qualifications on risk-taking propensity was tested using One-Way Analysis of Variance (ANOVA). The result is presented in Table $4 \mathrm{a}$ and $\mathrm{b}$. 
Table 4a: Summary of One-Way ANOVA Showing the Effects of Educational Levels on Risk-Taking Propensity

\begin{tabular}{|l|c|c|c|c|c|}
\hline Source & SS & Df & MS & F & P \\
\hline Within & 4432.337 & 3 & 1477.446 & 3.38 & $<.01$ \\
Between & 102261.7 & 234 & 437.016 & & \\
Total & 106694.1 & 237 & & & \\
\hline
\end{tabular}

The result shows a significant effect of levels of educational on risk-taking propensity of poultry farmers $(\mathrm{F}(3,234)=3.38 ; \mathrm{p}<.01)$. This means that the risk-taking propensity of participants with WASC/SSCE, OND/NCE, B.Sc/HND and postgraduate qualifications vary. However, the direction of the significant difference is not observable from the result in presented in Table 4a. Therefore, in order to know the direction of differences, a Post Hoc analysis of multiple comparison of the mean was done using Turkey HSD test. The result is presented in Table $4 \mathrm{~b}$.

Table 4b: Multiple Comparison Showing Group Differences on Risk-Taking Propensity Based on Participants Educational Qualification

\begin{tabular}{|c|c|c|c|c|c|c|c|}
\hline Level of Education & $\mathrm{N}$ & Mean & S.D & 1 & 2 & 3 & 4 \\
\hline 1. WASC/SSCE & 39 & 97.54 & 19.75 & - & & & \\
\hline 2. OND/NCE & 69 & 101.29 & 19.17 & -3.6644 & - & & \\
\hline 3. HND/B.Sc & 116 & 94.65 & 21.34 & 2.8919 & 6.5563 & - & \\
\hline 4. Postgraduate & 14 & 83.21 & 27.86 & 14.3243 & $17.9886^{*}$ & 11.432 & - \\
\hline
\end{tabular}

*The mean difference is significant at the .05 level

The result showed that participants with OND/NCE certificates significantly score higher on risk-taking propensity (Mean=101.29) compared to participants with postgraduate qualifications (Mean=83.21). However, participants with WASC/SSCE (Mean=97.54), participants with OND/NCE certificates (Mean=101.29), participants with HND/B.Sc (Mean=94.65) and participants with postgraduate qualifications (Mean=83.21) score comparably on risk-taking propensity. Also, participants with OND/NCE (Mean=101.29) and participants with HND/B.Sc (Mean=94.65) are likely to exhibit the same levels of risk-taking propensity. Lastly, participants with HND/B.Sc (Mean=94.65) and participants with postgraduate qualifications (Mean=83.21) do not differ significantly on risk-taking propensity. Therefore, hypothesis three is accepted.

\section{Discussion}

The results of the analyses supported an overall joint influence of perceived fear of failure, achievement motivation, locus of control, age, and year of poultry farming experience on risk-taking propensity of poultry farmers in this study. This finding 
suggests that it is informative to consider the combined influences of perceived of fear failure, achievement motivation, locus of control, age, and year of poultry farming experience in order to fully comprehend risk tasking propensity among poultry farmers.

Findings show that perceived fear of failure contributes more to the overall risktaking propensity, meaning that low scorers on fear of failure are likely to exhibit more risk-taking propensity. This may be because individuals who score low on perceived fear of failure are likely to believe that they can do better, then that thinking will limit him. If he believes that he can, he will succeed, if he does not believe he can, he will fail. This finding makes sense when considered in light of previous research. Empirical evidence from Lopes $(1984,1987)$ suggests that individual's risk propensity is significantly influenced by the degree to which he or she is motivated by hope or fear. A person's expectations about their life are very powerful, and a person's attitude is determined by their expectations contends Tracy (1993).

Locus of control contributes significantly to variation in risk-taking propensity, meaning that when locus of control is tilted towards externality individuals are likely to report more risk-taking propensity. This finding is consistent with Hendrickx, et al. (1992) finding that internals tend to estimate probability of failure as lower and decide in favor of risky options. Internal locus of control also leads to greater risk-taking behavior (Carland, et al, 1984; Stewart, et al., 1999). Internals are also found to plan for expansion of their businesses even when unemployment rates are high (Ward, 1993). A possible reason for this finding is that internal oriented individuals believe that it is their actions that affect the outcomes in their lives not luck, chance, fate, control of powerful others, or great complexity of the forces surrounding them, hence they are more likely to be informed, refuse to act impulsively, more likely to plan ahead, and act according to a plan when considering business risk.

The significant influence of need for achievement on risk-taking propensity, that is, high scorers on the need for achievement are likely to exhibit more risk-taking propensity seems to reflect a trend in the literature. For example, Ombok (1990, Cited in Mungai and Ogot, n.d.) reported that entrepreneurs who had high achievement motivation had a tendency towards risk taking. Johnson (1990) also found a relationship between achievement motivation and creation of new ventures. Probably individuals with high need for achievement have a strong need to be successful because they habitually spend time thinking about doing things better (McClelland, 1961).

Finding also showed that both male and female poultry farmers are likely to exhibit the same levels of risk-taking propensity. However, previous research suggested that there were differences in risk perception between men and women, with women judging health, safety, and recreational risks (Slovic, 1987; Finucane et al., 2000; Flynn et al., 1994) and also financial and ethical risks (Weber et al., forthcoming) to be larger and more problematic than men. The finding is also contrary to the findings of Carland et al., (1995) which indicate that females in their study displayed a lower level of risk taking 
propensity than did males.

Findings show that participants with OND/NCE certificates significantly score higher on risk-taking propensity compared to participants with postgraduate qualifications. However, participants with WASC/SSCE, participants with OND/NCE certificates, participants with HND/B.Sc and participants with postgraduate qualifications score comparably on risk-taking propensity. Also, participants with OND/NCE and participants with HND/B.Sc are likely to exhibit the same levels of risktaking propensity. Lastly, participants with HND/B.Sc and participants with postgraduate qualifications do not differ significantly on risk-taking propensity. The finding is consistent with those of the Carland et al., (1995) which affirm that higher levels of education led to higher propensities for risk taking among the participants in their study. Research (e.g., Hisrich and Peters, 1995; Brush, 1992) also suggest that entrepreneurs are better educated that the general public. The education levels of entrepreneurs tend to be above average (Brockhaus, 1982).

\section{CONCLUSION}

There is a significant negative relationship between perceived fear of failure and risktaking propensity, meaning that when perceived fear of failure is low, participants are likely to report more risk-taking propensity.

There is a significant positive relationship between need for achievement and risk-taking propensity, suggesting that when need for achievement increases, risk-taking propensity is likely to increase.

There is also a significant positive relationship between locus of control and risk-taking propensity, indicating that when locus of control tends towards internality, risk taking propensity is likely to increase.

The linear multiple regression analysis provided additional information about the joint and independent influence of perceived fear of failure, need for achievement, locus of control, and risk-taking propensity. The results from the linear multiple regression analysis provide support for the joint influence of perceived fear of failure, need for achievement, locus of control, age, and year of experience in poultry farming on risktaking propensity. Independently, perceived fear of failure, need for achievement, and locus of control contribute significantly to risk-taking propensity

The ANOVA test also revealed a significant difference between OND/NCE certificates holders and participants with postgraduate qualifications on risk-taking propensity.

\section{IMPLICATIONS OF FINDINGS}

These results have practical implications for improving participants' risk-taking propensity as well as the importance of conducting additional research in this area. While the results of this study echoed previous research with associated perceived fear of failure, need for achievement, locus of control and risk-taking propensity, it made a special contribution in linking perceived fear of failure, need for achievement, locus of 
control and risk-taking propensity in the context of poultry farmers. The apparent link between perceived fear of failure, need for achievement, locus of control and risk-taking propensity in poultry farmers' context has important implications for psychological intervention. For example, if the assessment data suggests that a poultry farmer has high scores on perceived fear of failure, need for achievement, locus of control, it might be useful to probe for more information regarding the farmer's risk-taking propensity. Based on these findings, it is necessary to carefully take into account the influence of perceived fear of failure, need for achievement, locus of control if one is to fully understand the risk-taking propensity of poultry farmers.

Lastly, the finding that OND/NCE certificates holders are likely to exhibit more risk-taking propensity compared to participants with postgraduate qualifications may suggest that, psychologists could help participants with postgraduate qualifications to improve their risk-taking propensity. In this regard, group counselling may be more beneficial in providing participants with postgraduate qualifications new orientation on risk-taking propensity in viable projects. Additionally, psychologists working on risktaking propensity should be sensitive to educational level differences, people with different levels of education are likely to exhibit different risk-taking propensity.

\section{RECOMMENDATIONS}

Based on the results of this study some recommendations are made for poultry farmer development and further research in this area.

First, poultry farmers association of Nigeria should organize seminars, trainings, and conferences for their members and through the assistance of experts should include an in-depth study of risk as a concept area of such seminars, trainings, and conferences. Content of the seminars, trainings, and conferences should include various perspectives of risk as well as risk-taking as it applies to poultry farming. Specifically, programmes could include methods for discerning both potential gains in innovation and creativity balanced with the potential costs of trying something new and different.

Second, poultry farmers should be given the opportunity to assess their own risk- taking propensities as an individual. This will enable them to develop an awareness of their risktaking style and can aid them in monitoring their risk-taking attitudes and behaviours and consider the influence their risk-taking style may have on their farm and on other associational members.

Next, risk-taking propensity training should include an awareness of the influence of certain psychological variables such as perceived fear of failure, achievement motivation and locus of control on an individual's risk-taking propensity.

The findings of this study suggest additional questions that could be addressed by future research studies. These additional questions and research ideas relate to replication of the study and the inclusion of other potentially relevant variables. Also, it would be useful to reproduce this study across different samples in order to increase generalizability. 


\section{LIMITATION OF STUDY}

There are some limitations relevant to the study that could affect the generalization of the findings. The exploratory and correlational nature of the study, this study is the first to examine perceived fear of failure, achievement motivation, and locus of control on risk-taking propensity among poultry farmers. Given the study's exploratory nature, it should be replicated to see if the results are sustained before the findings are generalized. Similarly, the correlational nature of the study does not allow the researcher to control for all extraneous variables, thus some variables may be relating with the independent variables to affect the dependent variable. Lastly, the findings have limited generalizability due to the sampling method. The sample for the study was drawn among members of Poultry Farmers Association of Nigerian, Ibadan Branch; results can not be generalized to other poultry farmers in Nigeria.

\section{REFERENCES}

Atkinson, J. W. (1957). Motivational Determinant of Risk-taking Behavior. Psychological Review, 64: 359-372.

Atkinson, J. W. (1974). Motivation and Achievement. Washington, D.C: V. H. Winston and Sons.

Atkinson, J. \& Feather, N. (1966). A Theory of Achievement Motivation. New York: Wiley and Sons.

Babalola, S. S. (2000). The Influence of Self-esteem, Need for Achievement and Sense Of Competence on Perceived Business Success. African Journal for the Psychological Study of Social Issues, 5 (2): 127-137.

Brockhaus, R.H. (1982) The Psychology of the Entrepreneur. In C.A. Kent, D. Sexton and K. Vesper (Eds.) Encyclopaedia of Entrepreneurship. Prentice Hall

Brush, C.G. (1992) Research on Women Business Owners: Past Trends, A New Perspective and Future Directions. Entrepreneurship Theory and Practice, 16 (4): 529.

Carland, J. W., Hoy, F., Boulton, W. R., \& Carland, J. A. (1984). Differentiating Entrepreneurs from Small Business Owners: A Conceptualization. Academy of Management Review, 9(2): 354-359.

COMSIS Corporation \& Johns Hopkins University, (1995). Understanding Youthful Risk Taking and Driving. Washington, DC: National Highway Traffic Safety. 
Balogun, Ojedokun \& Macaulay

Conroy, M. A. (Ed) (2003). Prevention and Early Intervention for Young Children at Risk for Emotional or Behavioral Disorder. Reston: CCBD

Conroy, D. E, Willow, J. P, \& Metzler, J. N. (2002). Multidimensional Fear of Failure Measurement: The Performance Failure Appraisal Inventory. Journal of Applied Sport Psychology, 14: 76-90.

Craig, A. R, Franklin, J.A, \& Andrew, G. (1984). Scale to Measure Locus of Control of Behaviour. British Journal of Medicine, 57: 173-180.

Denenberg, H.S., Eilers, R. D., Hoffman, G. W., Kline, C. A. Melone, J. J. and Snider, H. W. (1964) Risk and Insurance Englewood Cliffs, New Jersey: Prentice Hall.

Denenberg, H.S. and Ferrari, J.R. (1966) New Perspectives on Risk Management: The Search for Principles. The Journal of Risk and Insurance, 33(4): 654 655.

Edward, W. (1954). The Theory of Decision Making. Psychological Bulletin, 51: 380417.

Elliot, A. J., \& McGregor, H. A. (1999). Test Anxiety and the Hierarchical Model of Approach and Avoidance Achievement Motivation. Journal of Personality and Social Psychology, 76: 628-644.

Elmore, P. B., \& Lewis, E. L. (1991). Statistics and Computer Attitude and Achievement of Students who Enrolled in Applied Statistics: Effects of Computer Laboratory. Paper Presented at the Annual Meeting of the American Educational Research Association, Chicago, IL.

Farley, F. (1986). The Big T in Personality. Psychology Today, May 1986: 45-52.

Finucane, M.L., Slovic, P, Mertz, C.K., Flynn, J and Satterfield, T.A. (2000). Gender, Race, and Perceived Risk: The "White Male" Effect. Health Risk and Society, 2(2): 159 - 172.

Flynn ,J. Slovic, P. and Mertz, C.K. (1994). Gender, Race, and Perception of Environmental Health Risks. Risk Analysis, 14: 11011108.

Furby, L., \& Beyth-Marom, R. (1992). Risk Taking in Adolescence: A Decision Making Perspective. Developmental Review, 12: 1-44. 
Balogun, Ojedokun \& Macaulay

Gardener, W. (1993). A Life Span Rational Choice Theory of Risk Taking. In N.J. Bell and R.W. Bell (Eds). Adolescent Risk Taking. California: Sage

Harackiewicz, J. M., Barron, K. E., Carter, S. M., Lehto, A. T., \& Elliot, A. J. (1997). Predictors and Consequences of Achievement Goals in the College Classroom: Maintaining Interest and Making the Grade. Journal of Personality and Social Psychology, 73: 1284-1295.

Harnett, D. L., \& Cummings, L. L. (1980). Bargaining Behavior: An International Study. Dame Publications, Houston.

Hendrickx, L., Vlek, C., and Calje, H. (1992). Effects of Frequency and Uncertainty: Heuristics and Biases. Cambridge: Cambridge University Press.

Hisrich, R.D. and Peters, M.P (1998). Entrepreneurship. New York: Prentice Hall

Horner, M. (1972). Toward an Understanding of Achievement Related Conflicts in Women. Journal of Social Issues, 28(2): 157 - 174.

Johnson, B. R. (1990). Toward a Multidimensional Model of Entrepreneurship: The Case of Achievement Motivation and the Entrepreneur. Entrepreneurship Theory and Practice, 14(3): 39-54.

Johnson, G. L., Halter, A. N., Jensen, H. R., and Thomas, D. W. (Eds). (1961). A Study of Managerial Processes of Mid-Western Farmers. Iowa State University Press, Ames, $221 \mathrm{pp}$

Keil, M., Wallace, L., Turk, D., Dixon-Randall, G., \& Nulden, U. (2000). An Investigation of Risk Perception and Risk Propensity on the Decision to Continue a Software Development Project. The Journal of Systems and Software, 53 (2000): 145-157.

Kogan, N., \& Wallach, M. A. (1964). Risk Taking: A Study in Cognition and Personality. New York: Holt, Rinehart \& Winston.

Kunreuther, H., \& Wright, G. (1979). Safety-first, Gambling, and the Subsistence Farmer. In, Risk, Uncertainty and Agricultural Development. New York: Agricultural Development Council. 
Lopez, F. G. (1984). Family Dynamics and Late Adolescent Identity Development. In Brown and Lent (Eds.), Handbook of Counseling Psychology. (2nd ed.): 251283. New York: Wiley.

Lopez, F. G. (1987). Erickson and Rogers: The Differences do make a Difference. Journal of Counselling and Development, 65: 241-243.

McClelland, D. C. (1961). The Achieving Society. Princeton, NJ: Van Nostrand.

McClelland, D. C, Atkinson, J. W, Clark, R. A, \& Lowell, E. L. (1953). The achievement motive. New York: Appleton-Century-Croft.

Mehr, I., and Cammack, E. (1961)._Principles of Insurance (4 $4^{\text {th }}$ edition). Homewood, Illinois: Richard D. Irwin,

Mungai, E.N. and Ogot, M (nd). Ethnicity, Culture and Entrepreneurship in Kenya. (Document posted on the web.)

Oyefeso (1988). Oyefeso, A. O. (1988). Cross Validation of Edward Personal Schedule. Unpublished Research Paper, University of Ibadan, Ibadan.

Rabel W.H. (1968). Further Comment. The Journal of Risk and Insurance, 35(4): $611-612$.

Carland, J.W., Carland, J.W., Carland, J.A. and Pearce, J.W. (1995). Risk Taking Propensity Among Entrepreneurs, Small Business Owners, and Managers. Journal of Business Venturing, 12: 9- 30.

Rohrmann, B. (2004). The Relevance of the Internet for Enhancing Disaster Preparedness of Residents. Proceedings, 11th Conference of the International Emergency Management Society(TIEMS), May 2004.

Rotter, J. B. (1966). Generalised Expectancies for Internal Versus External Control of Reinforcement. Psychological Monographs, 80.

Sagar, S. S., Lavallee, D., and Spray, C. M. (2007). Why Young Elite Athletes Fear Failure: Consequences of failure. Journal of Sports Sciences, 25: 1171-1184.

Shane, S. (2003). A General Theory of Entrepreneurship: The Individual Opportunity Nexus. Cheltenham, UK: Edward Elgar. 
Balogun, Ojedokun \& Macaulay

Shane, S., \& Venkataraman, S. (2000). The Promise of Entrepreneurship as a Field of Research.Academy of Management Review, 25 (1): 217- 226.

Sitkin, S.B., \& Pablo, A. L. (1992). Reconceptualizing the Determinants of Risk Behavior. Academy of Management Review, 17 (1): 9-38.

Slovic, P. (1997). Trust, Emotion, Sex, Politics, and Science: Surveying the Risk Assessment Battlefield. In M.H. Bazerman, D.M Messick, Tenbrunsel, A.E. and Wade-Benzoivi (Eds.) Environment, Ethics, and Behaviour. San Frasisco: New Lexington.

Stewart, Jr. W. H, Watson, W. E, Carland, J. C \& Carland, J. W. (1999). A Proclivity for Bntrepreneurship: A Comparative Study of Entrepreneurs, Small Business Owners and Corporate Managers. Journal of Business Venturing, 14(20): 189 -214.

Tracy, B (1993) Maximum Achievement. New York: Simon and Schuster

Tversky, A, \& Fox, C. R. (1995). Weighing Risk and Uncertainty, Psychological Review, 102(2): 269-283.

Von Winterfeldt, D., \& Edwards, W. (1986). Decision Analysis and Behavioral Rsearch. New York: Cambridge University Press.

Ward E.A. (1993). Motivation of Expansion Plans of Entrepreneurs and Small Business Managers. Journal of Small Business Management, 31(1): 32-38.

Weber, E.U. Daniels A and Ann-Blais, B (Fort coming). How Do I Choose thee? Let $\mathrm{m}$ e Count the Ways". A Textual Analysis of Similarities and Differences in Modes of Decision Making in the USA and China. Management and Organisation Review

Woelke, P. L (1991). An Examination of the Factor Structure of Wise's Attitude Toward Statistics Scale. Paper presented at the annual meeting of the American Educational Research Association, Chicago, IL.

Yates, J. F., \& Stone, E. R. (1992). In: Yates, J.F. (1992) (Ed.). The Risk Construct in RiskTaking Behavior. Wiley, Chichester, 1-25.

Zeidner, M. (1991). Statistics and Mathematics Anxiety in Social Science Students some interesting parallels, British Journal of Educational Psychology, 61:319-328. 